\title{
SIMBOL ORDO ILLUMINATI DALAM KEHIDUPAN SOSIO - KULTURAL MUSLIM DI ARAB SAUDI: ANALISIS SEMIOTIK SIMBOLIK
}

\author{
Ani Choirun Nisa \\ sabilaassyahidah@gmail.com \\ M. Farkhan M \\ farchanmd@yahoo.com \\ Prodi Sastra Arab Fakultas Ilmu Budaya \\ Universitas Sebelas Maret Surakarta
}

\begin{abstract}
Illumination Ordo is one of the international secret organization. The aim of this organization is to build a new world arrangement which has a significant role in several countries. And Saudi Arabia is one of those countries. This study discussed the history factors that lie behind the phenomenon of the use of Ordo Illuminati symbols by moslem in Saudi Arabia and Aspects of life that associated with the use of Ordo Illuminati symbols in Saudi Arabia.The method of this study was descriptive qualitative by using library research technique which followed 4 steps; they are: (1) making a research plan, (2) collecting the data, (3) analyzing the data, (4) and writing the report. Moreover, the theory used in this study was semiotic symbolic which is proposed by Charles Sander Pierce. Based on this study, there are two conclusions; they are: (1) the history factor that lie behind the phenomenon of the use of Ordo Illuminati symbols by moslem in Saudi Arabia. (2) Aspects of life that associated with the use of Ordo Illuminati symbols in Saudi Arabia.
\end{abstract}

Keywords: Illuminati Ordo, Symbol, New World Order, Mosleem.

$$
\begin{aligned}
& \text { ملخص البحث } \\
& \text { أردو إللوميناتى هي منظمة دولية موصوفة بالسِّرِّ. قصد هذه المنظمة تكوينالنظام العالمالجديد. وتلعب دورا مهما } \\
& \text { في الدول الكثيرةمنهالمملكةالعربية السعودية. يتناول هذا البحثالخلفيات التاريخية فن ظهور استخدامرموز أردو } \\
& \text { إللوميناتللمسلمين في المملكة العربية السعودية والجوانب التى تتعلق باستخدامرموز أردو إللوميناتى للمسلمين في }
\end{aligned}
$$

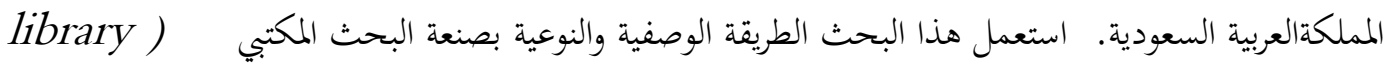

$$
\begin{aligned}
& \text { (research } \\
& \text { البحث نظريةسيميوطيقيةلتثارلز ساندر بيرس. وبناء على هذا البحث، يستخلص أمران:أولا، أندبلوماسية بين } \\
& \text { الغرب والمملكة العربية السعودية، تفتح الفرص لأردو اللوميناتى لتدخل رموزها في المملكة العربية السعودية، ثانيا، }
\end{aligned}
$$




$$
\text { والإتململ إستخدام رموز أردو إللوميناتى في المملكةالعربية السعودية على الجوانب الهندسية والمعمارية، والموسيقية، }
$$

\section{A. Pendahuluan}

Ordo Illuminati merupakan sebuah kelompok keagamaan ayau yang berkaitan dengan paham keyakinan dan keagamaan yang dilandasi oleh penguasaan iptek, intelektual, dan finansial. Organisasi ini beranggotakan para ilmuan terkenal, penguasa berpengaruh, saudagar kaya. Ordo ini sering memakai simbol-simbol dan memiliki tujuan untuk mewujudkan dan membentuk tatanan dunia baru (Ezza, 2014:06).

Simbol Ordo Illuminati telah mempengaruhi perkembangan berbagai negara di dunia, salah satunya ialah Arab Saudi.Arab Saudi merupakan negara dengan mayoritas masyarakat beragama Islam.Makkah merupakan salah satu kota di negara Arab Saudi yang memiliki banyak perubahan secara simbolik baik dari segi bangunan maupun yang lainnya (2014:58).

Simbol adalah bentuk yang menandai sesuatu yang lain diluar perwujudan bentuk simbolik itu sendiri artinya simbol mengacukan kepada suatu hal lain yang berasal dari dalam atau diluar dari yang diacukan tadi. Dalam Kamus Besar Bahasa Indonesia Edisi Ketiga disebutkan bahwa "simbol adalah kata lain dari lambang, yaitu sesuatu seperti tanda (lukisan, lencana, dan sebagainya) yang menyatakan suatu hal atau mengandung maksud tertentu" (2001:166)

Semiotika adalah ilmu tentang tanda.Tanda disini merupakan segala sesuatu yang didalamnya terkandung makna.

Sobur

(2004:15)

mengatakan,Semiotika adalah suatu ilmu atau metode analisis untuk mengkaji tanda, yang mana dalam setiap tanda tersebut menandakan sesuatu.Manusia dengan perantara tanda-tanda, dapat melakukan komunikasi dengan sesamanya.Dalam kehidupan sehari-hari terdapat tanda dalam bentuk yang beraneka ragam yang menyampaikan informasi sehingga bersifat komunikatif.

Menurut Peirce (dalam Budiman, 2011:1), semiotika tidak lain dari sebuah nama lain bagi logika, yakni "doktrin formal tentang tanda-tanda", karena logika adalah mempelajari bagaimana orang bernalar dan penalaran tersebut melalui tanda-tanda. Dalam pandangan Peirce, semiotika berangkat dari tiga elemen utama, yaitu teori Segitiga Makna:tanda, objek dan interpretan. Menurut Carles Sanders Peirce, tanda terdiri dari beberapa katagori, yaitu ikon, indeks, dan symbol (Kriyantono, 2006:267)

Permasalahan dalam penelitian ini adalah: 1) Apa yang melatarbelakangi penggunaan simbol Ordo Illuminati oleh Muslim di Arab Saudi? 2) Aspek kehidupan apa saja terkait dengan penggunaan simbol-simbol Ordo Illuminati di Arab Saudi?

Tujuan penelitian ini adalah: 1) Menjelaskan penyebab yang melatarbelakangi penggunaan simbol Ordo Illuminati oleh Muslim di Arab Saudi, 2) Menjelaskan aspek kehidupan yang terkait dengan penggunaan simbol-simbol Ordo Illuminati di Arab 
Saudi dari segi seni bangunan, seni musik, dan sosial.

\section{B. Pembahasan}

1. Latarbelakang Pemakaian Simbol Ordo Illuminati Oleh Muslim Di Arab Saudi.

Bermula pada tahun $851 \mathrm{H}$, seorang pedagang gandum Yahudi bernama Mordakhai bin Ibrahim bin Moshe melakukan kerjasama perdagangan dengan kaum Bani AlMasalikh. Pada saat itu tidak ada yang mengetahui bahwasannya dibalik pikiran dan hati Mordakhai terdapat suatu kepentingan kapital dan kekuasaan (Ezza, 2014:46).

Mordakhai mulai melancarkan aksi propaganda dari satu wilayah ke wilayah lain, dengan menyampaikan suatu paham dan ajaran menyimpang. Sedikit demi sedikit usaha propagandanya berhasil mempengaruhi masyarakat dan dengan pengaruhnya tersebut, ia menjadikan Dir'iyah sebagai pusat kekuasaannya. Kemudian ia menikahi wanita-wanita Arab hingga ia dikaruniai beberapa anak. Salah seorang anak Mordakhai bernama AlMaqaran mempunyai anak bernama Muhammad, dan anak yang lainnya bernama Saud, dari keturunan Saud inilah Dinasti Saudi berasal (2014:50).

Sejarah singkat inilah yang memulai awal berdirinya Ordo Illuminati Saudi Arabia yang belum banyak orang ketahui (2014:52).Kemudian para raja Arab keturunan Yahudi begitu mudahnya untuk membuka diplomasi dengan negara-negara barat seperti Amerika Serikat dan Inggris.Dari hal ini, kemudian Ordo Illuminati yang merupakan pemimpin-pemimpin dunia dengan mudahnya masuk sebagai bagian dari Negara Arab Saudi.

Arab Saudi merupakan sebuah negara dengan otoritasnya di bawah kepemimpinan Raja, dan mayoritas pemeluk agama Islam.Perkembangan industri perminyakan di Arab Saudi sejak 1930 M membuat Arab Saudi menjadi negara yang paling diseganisemenjak negara ini memiliki hubungan diplomasi dengan negara Amerika (Simmons, $2005: 5$ ).

Keterbukaan negara Arab dengan Barat membuat perubahan hampir di seluruh tatanan masyarakat di berbagai aspek, seperti pemikiran yang lebih modern, budaya, bangunan, dan sebagainya.Peradaban Barat ini telah membawa perubahanbagitradisi Arab menjadi sebuah tradisi yang lebih modern.Nilai-nilai agama yang merupakan sumber kekuatan masyarakat Arab dan solidaritasnya mulai berkurang. Hal ini tidak lepas dari campur tangan elit Ordo Illuminati untuk menghancurkan peradaban agama Islam dengan dalih ingin menjadikan Arab Saudi selayaknya kota New York.Pemerintah Arab Saudi mendatangkan para arsitek dari baratuntuk membantu membangun berbagai bangunan seperti museum, sekolah, rumah sakit, mall. Dengan adanya para arstitek barat ini, pembangunandi wilayah Arab Saudi dengan mudahnya disisipi simbolsimbol Ordo Illuminati(Ezza, 2014:58).

Selain bangunan, pengaruh barat juga membuat pemikiran masyarakat Arab Saudi menjadi lebih modern.Salah satu cara mempengaruhi masyarakatnya yaitu dengan didatangkanindustri musik barat seperti tayangan film dan musik di televisi maupun radio, hal ini memberikan pengaruh besar terhadap pemikiran 
para pemuda Arab Saudi. Televisi dan radio merupakan sarana paling sempurna untuk dijadikan program mind control, sebab dengan media ini Ordo Illuminati bisa banyak menyusupkan simbol-simbolnya melalui gambar dan lirik lagu(Makow, 2011:61). Pada aspek lain, mereka juga menyusupkan simbol-simbol pada seragam-seragam militer, logo-logo resmi pemerintahan, logo Badan Urusan Haji Saudi, museum-museum, rumah sakit, sekolah dan masih banyak lagi

2. Aspek Kehidupan Terkait Dengan Penggunaan Simbol-Simbol Ordo Illuminati.

Aspek kehidupan sebuah masyarakat tentunya juga mempengaruhi cara dan gaya hidup suatu masyarakat tersebut.Dengan adanya simbol, membantu kita mempertajam tingkah laku dan prestasi kebudayaan.Ada beberapa aspek kehidupan masyarakat Arab Saudi terkait dengan penggunaan simbol- simbol Ordo Illuminati. Aspek kehidupan ini meliputi:aspek sosial, seni bangunan, seni music..Berikut adalah analisis simbol tersebut berdasarkan analisis semiotika berdasarkan pendekatan teori semiotik Charles Sander Peirce.

\section{a. Seni Bangunan.}

Arab Saudi yang menyandang sebutan sebagai pusat peradaban Islam dan salah satu kotanya yaitu Makkah yangmenjadi pusat ibadah haji umat Islam di seluruh dunia. Akan tetapi, saat ini Ka'bah semakin tenggelam oleh berdirinya gedunggedung tinggi di sekitarnya.Di bawah ini adalah proyek gambaran kota suci Mekah mendatang, jika dilihat dari sisi atas maka akan terlihat seperti sebuah bentuk okultisme. Okultisme merupakan motif jalan berbentuk delapan arah ini sering dikaitkan dengan chaos, dalam istilah agama berarti jalan selain jalan yang lurus (Berger, 2010:177).

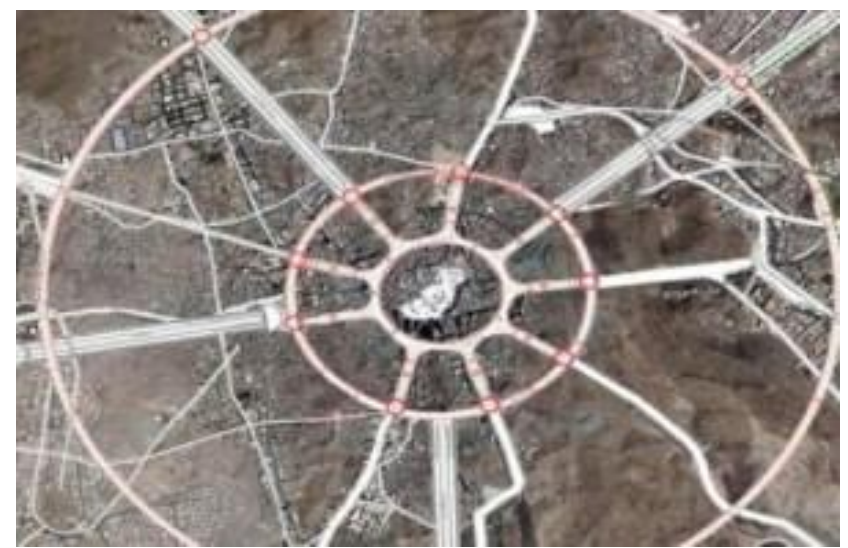

Gambar 1: rencana pembangunan sekitar Ka'bah yang membentuk seperti symbol Chaos. (https://dwiheriyanto.wordpress.com). 
Dalam Ordo IlluminatiChaos dapat diartikan sebagai ketidakteraturan, kekacauan, keruwetan dan sebagainya. Dalam Islam, chaos timbul ketika hukum Allah mulai dicampakkan dan dipisahkan dari kehidupan, yang biasa disebut dengan sekulerisme (Purbawati, 2014:140).

Dalam hal ini, Ordo Illuminati menganggap bahwa hukum Allah SWT hanya sebagai ibadah ritual saja.Kemudian manusia membuat hukumnya sendiri dan menolak hokum Allah. Namun hukumnya penuh dengan kelemahan, dan akhirnya hanya akan menimbulkan ketimpangan dan kesengsaraan, yaitu kesengsaraan di dunia maupun di akhirat. Allah kemudian berfirman di dalam Al Qur'an suratAl Ma'idah ayat 49:

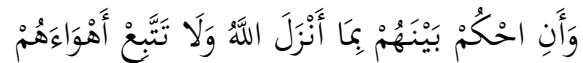

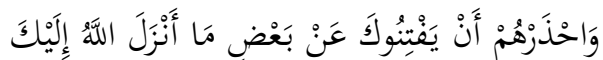

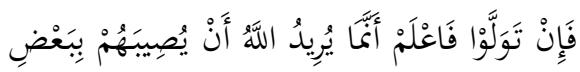

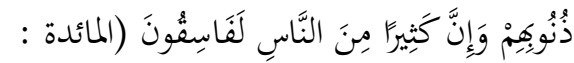

Waannī-chkum

bainahum

bimā anzala 'l-Lāhu walà tattabi' ahwā-ahum wāchdzarhum an yaftinūka 'an ba'dhi mā anzala '1Lāhu ilaika fain tawallaū fälam annamā yurīdu 'l-Lāhu an yushībahum biba'dhi dzunübihim wa-inna katsìran mina 'n-nāsi lafäsiqūna

"Dan hendaklah kamu memutuskan perkara di antara mereka menurut apa yang diturunkan Allah, dan janganlah kamu mengikuti hawa nafsu mereka. Dan berhati-hatilah kamu terhadap mereka, supaya mereka tidak memalingkan kamu dari sebahagian apa yang telah diturunkan Allah kepadamu. Jika mereka berpaling (dari hukum yang telah diturunkan Allah), maka ketahuilah bahwa sesungguhnya Allah menghendaki akan menimpakan musibah kepada mereka disebabkan sebahagian dosa-dosa mereka. Dan sesungguhnya kebanyakan manusia adalah orang-orang yang fasik." (QS Al Ma'idah: 49)

b. Seni Musik.

Musik merupakan salah satu media seni yang digunakan Ordo Illuminati, dan berperan sangat penting untuk mengendalikan pemikiran manusia.Sebagai negara yang menjujung tinggi perdamaian dengan barat, Arab Saudi juga menyelenggarakan acaramusik, bernama Arab Idol (Gray, 2005:107).

Muhammad Pizaro Novelan Tauhidi, seorang pengamat sekaligus koordinator Kajian Zionisme Internasional (KaZI) memberikan opininya bahwa ada skenario zionis Yahudi (Ordo Illuminati) pada ajang acara pencarian bakat dan sejenisnya. Ajang pencarian bakat sebenarnya tidak lepas dari program Yahudi. Mereka sadar cara paling ampuh melumpuhkan para pemuda muslim adalah menjauhkan mereka dari gaya hidup Islam dan mendekatkan mereka pada hedonisme dan hiburan. Hal inilah yang dikatakan Gleed Stones 
mantan Perdana Menteri Inggris.

Dia mengatakan:

"Percuma kita memerangi umat Islam, dan tidak akan mampu menguasainya selama di dada pemuda-pemuda Islam ini bertengger Al-Qur'an. Tugas kita sekarang adalah mencabut Al-Qur'an di hati-hati mereka, baru kita akan menang dan menguasai mereka. Minuman keras dan musik lebih menghancurkan ummat Muhammad SAW dari pada seribu meriam, oleh karena itu, tanamkanlah dalam hati mereka rasa cinta terhadap materi dan seks."

(http://www.arrahmah.com)

Propaganda Ordo Illuminati di dalam acara Arab Idol yaitu terdapat simbolmata satu pada design latar belakang panggung. Simbol mata satumerupakan simbol utamaOrdo Illuminati, simbol inibertujuan memantau segala kegiatan manusia (Gray, 2005:4)

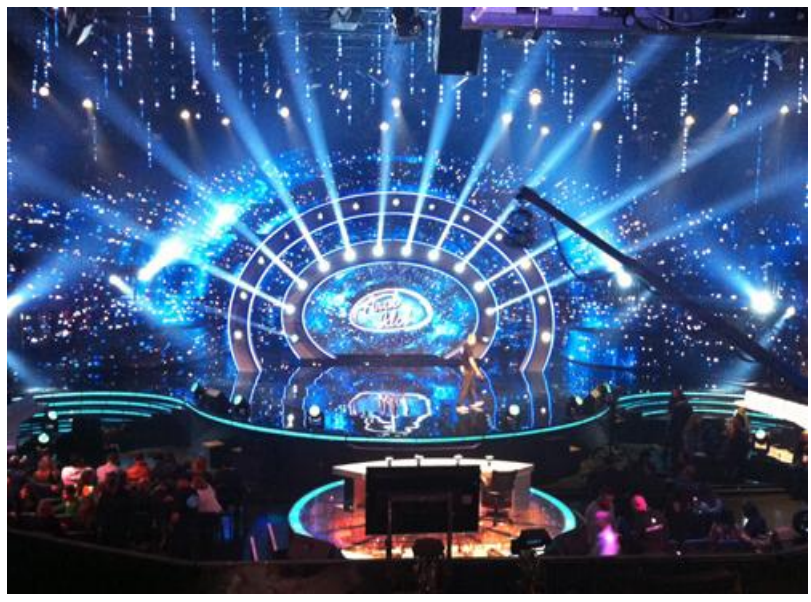

Gambar 2: simbol mata satu yang bercahaya pada latar panggung Arab Idol (http://www.digitalproductionme.com

Simbol pada keterangan gambar di atas merujuk pada Mata Horus yang merupakan simbol mistik dari kekuatan gelap yang bermakna Maha Tahu dan Maha melihat dan biasanya dilukis dalam hieroglif di dinding-dinding piramida pada masa Mesir Kuno (Junus, 2013:61).Junus menambahkan, simbol Mata Horus merupakan salah satu simbol yang sering digunakan dalam simbol Illuminati.Bentuk tersebut identik dengan simbol Illuminati, karena simbol kemenangan merekaberada dimana saja, carilah titik dalam lingkaran, piramida, dan Mata Horus (mata iblis) dan arsiran yang menggambarkan matahari terbit (Makow, 2012:145).Cahaya yang mengelilingi penggambaran mata satu tersebut bermakna cahaya yang menerangi seluruh panggung, atau jika di analisis menurut Peirce, cahaya ini secara tidak langsung bermakna menerangi seluruh dunia.

Dari simbol yang telah dijelaskan tersebut, menunjukkan bahwa budaya yang disediakan oleh pasar hiburan komersial memainkan salah satu peran penting bagi Ordo 
Illuminati. Ia mencerminkan sikap dan sentimen yang telah ada di sana. Pada saat bersamaan menyediakan wilayah yang penuh ekspresi serta sederet simbol. Maka melalui simbol tersebut sikap tersebut diproyeksikan (Storey, 2010:126).

\section{c. Ekonomi}

Ordo Illmuninati akan bersatu untuk berserikat dalam harta dan anak mereka, maksudnya dalam agen-agennya di dunia akan membentuk item yang mengatur monopoli ekonomi setiap orang dan menjamin keberlangsungan kehidupan generasi mereka, karena ketergantungan manusia terhadap sitem tersebut menjadikan harta dan anak-anak serta sistem yang ada seolah-olah menjadi miliki bersama antara seseorang dengan pemilik sistem (ordo Illuminati, inilah yang dimakud dengan mencamnpuradukkan dua kepemilikan.

Pemahaman tentang makna syirkah, yang bersaal dari syaraka, yusyariku, musyarakah sebagai mencampurkan dua kepemilikian dalam kontek dewasa ini menunjukkan adanya monopoli ekonomi, yakni ekonomi keuangan seluruh dunia yang berpusat di tangan para bankir yang bermarkas di City of London, Identitas mereka yang sangat rahasia, namun menurut Henry Makow bahwa salah satu dari mereka ialah keluarga Rotchilds, jaringan ini disebut oleh American Almanac sebagai Club of The Isle, sebuah perkumpulan informal dari rumah tangga kerajaan yang berada di Eropa, termasuk Queen (Ratu). Mereka menguasai aset sebanyak \$ 10 trilyun, dan mengendalikan korporasi-korporasi raksasa seperti Royal Dutch shell, Imperial Chemical industries, Lyold of London, Unilever, Lonrho, Rio rinto Zinc dan Anglo Amirican DeBeer, mereka mendominasi pasokan minyak, permata, dan banyak lagi bahan mentah penting lainnya untuk mewujudkan tujuan geopolitik mereka. Merekalah yang membuat sitem uang kertas, mereka juga yang memberikan ijin kepada negaranegara di dunia untuk mencetak uangnya. Hakikat uang kertas yang tidak berharga membuat nilainya menjadi tidak stabil sehingga mudah mengalami inflasi. Karena harta semua ini telah mereka kuasai maka mudah sekali bagi mereka untuk menciptakan krisis ekonomi global, inilah monopoli ekonomi. Dengan adanya sistem terebut menjadikan orientasi manusia terbatas pada pemenuhanpemenuhan materi sehingga perhatian terhadap agama menjadi sangat kurang, sehingga hal terebut mengakibatkan rentan dengan praktek perzinaan dan pemenuhan kebutuhan hidup dengan cara yang haram. Keadaan ini menjadikan manusia berada di bawah penguasaan iblis, sehingga tanpa disadari mereka leluasa dalam menjalankan kesesatan-kesesatan. Dengan keadaan faqir dan kekhawatiran manusia terhadap keturunannya serta hilangnya perhatian mereka terhadap agama akan membuat manusia menjadi mudah di kontrol dan diarahkan sesuakanya. ( Henry, 2020 : 59-61).

Negara Arab juga membuat relasi dengan Amerika dalam hal industri perminyakan. Penemuan minyak menjadi titik transisi baru 
bagi perpolitikan Arabs audi. sebelum 1930 M, Arab saudi adalah negara yang dianggap tidak memiliki apa-apa dari segi sumber daya. Minyak merubah wajah politik Arab saudi di mata dunia sehingga Amerika serikat menjadikan Arab saudi sebagai sekutu. Kerjasama yang dibangun antara Amerika Arab saudi menjadi taraf ekonomi Arab saudi menjadi semakin tinggi kedudukannya dibanding negaranegara Arab lainnya.

Melalui sektor ekonomi ini pembangunan menjadi sangat pesat dan menjadikan wilayah Arab saudi menjadi negara petro dollar modern. Negara ini telah menasionalisasi perusahaan minyak yang dikelola Amerika erikat dengan nama ARAMCO pada tahun 1974 M lewat Raja Faial. Melalui raja faial inilah audi yang dahulunya mikin menjadi makmurhingga ekarang. ( amantho, $2014: 218$ )

Sebagai sebuah lembaga besar, ARAMCO memiliki sebuah logo atau simbol yang menandakan keeksisteninannya sebagai perusahaan besar dan logo yang dipakai oleh kerajaan Arab saudi untuk melambangkan ARAMCO ini memakai lambang dari salah satu ordo Illuminati dan freemasonry, sebuah segitiga ditengah-tengah lingkaran

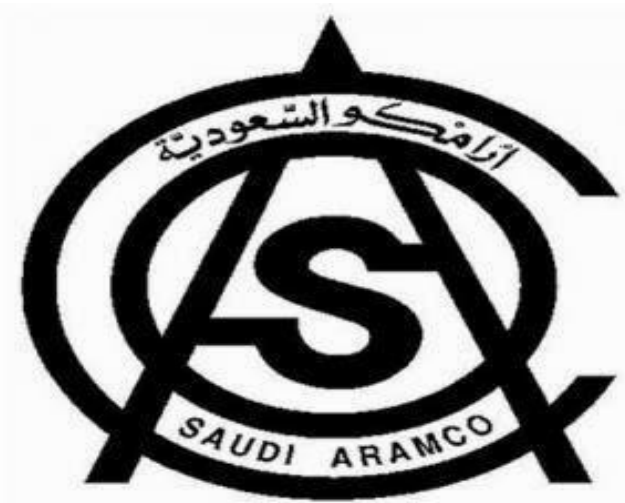

Gambar 3: Lambang ARAMCO

Jika dilihat secara simboliss, logo Aramco ini menyerupai piramida yang berada di tengah lingkaran. Piramida merupakan representasi perwujudan berupa aktivitas penyembahan kabbalis kepada Iblis Lucifer. Yang haru dipahami dari makna imbol ini adalah persamaan dari piramida ebagai imbol utama yang mewakili miteri peradaban kuno yaitu keluhuran dalam keederhanaan mereka, ilahi dalam propori mereka. Mereka mewujudkan pengetahuan ilahi yang dimiliki oleh yang tercerahkan (illuminated). Dari ini kaum elit ordo Illumintai mendedikaikan diri ebagai okultime, yaitu ahli wari dari kebijakanaan kuno dan menggunakan piramida ebagai imbol kekuaaan di dunia modern.

Puncak segitiga yang tidak sempurna menandakan segitiga batu ata piramid yang terang , 
mengambang atau hilang, yaitu mewakili kehadiran Ilahi di alam semesta serta dalam setiap manusia. Arti simbolis lain dikaitkan dengan batu penjuru yang hilang sebagai sifat yang belum selesai dari gerakan Tata Dunia Baru ( New Worl Order). Disebutkan bahwa puncak segitiga penjuru dari dari Piramida Besar akan diaktifkan kembali ketika proyek yang telah berusia lama ini menjadi kenyataan. Kaum ordo Illuminati juga menggunakan bangunan piramida untuk merepresentasikan struktur hirarki mereka, dengan cara para elit Ordo illumintai duduk pada puncak piramida untuk menguasai massa yang berkewajiban menopang piramida tersebut ( Jagad, 2013: 31).

\section{d. Pemerintahan}

Pemerintahan Arab saudi menggunakan item kerajaan atau monarki dan Ilam sebagai bentuk pemerintahannya. Alquran dan syariat Islam menjadi dasar dari sistem yang dijalankan. sistem pemerintahan Arab saudi merupakan presidenisil karena dipimpin oleh seorang raja. Raja selain menjadi kepala negara juga memiliki beberapa peran sehingga sitem pemerintahannya disebut sebagai monarki absolut ( http://ilmakriboo.worldpress.com/20 13/12/26/sistem-pemerintahansaudi-arabia/diakes 11 Nopember 2015, pukul 08.40). saat ini Arab saudi dipimpin oleh raja Abdullah bin Abdul Azis Al saud, yang diangkat menjadi raja pada tahun 2005 M menggantikan raja Fahd yang telah meninggal. selain sebagai pemimpin negara raja Abdullah bin Abdul Azis Al saud juga merangkap jabatan sebagai perdana menteri dan pemerintahan.

Kerajaan saudi Arabia memiliki landasan bagi sistem pemerintahan di wilayah tersebut, lingkungan resmi yang mengaturnya, unsur-unsur fundamental masyarakat saudi, prinsip-prinsip ekonomi umum yang dilaksanakan kerajaan, jaminan negara terhadap kebebasan dan kehormatan ata kepemilikian khusus, perlindungan atas hak-hak asasi manusia seusai dengan hukumhukum syari'at Islam. Kerajaan itu juga menetapkan hak dan kewajiban negara dan hubungannya dengan negara-negara lain, dan negara memberikan perhatian terhadap Ilmu pengetahuan dan sastra, serta menyediakan perawatan keehatan. Di samping itu, hukum-hukum tentang layanan kemiliteran dan kewajiban warga negara dalam mempertahankan aqidah islamiyah, masyarakat dan tanah air. Undangundang juga menetapkan hal-hal yang berhubungan dengan pemerintahan, kehormatan tempat tinggal dan sanksi, hak suaka politik, kewajiban dan hak warga negara asing yang bertempat tinggal di wilayah tersebut. ( http://www.cribd.com/doc/6602356 9/2015 pkl 11.00).

ika dilihat secara simboliss, logo Aramco ini menyerupai piramida yang berada di tengah lingkaran. Piramida merupakan representasi perwujudan berupa aktivitas penyembahan kabbalis kepada Iblis Lucifer. Yang haru 
dipahami dari makna imbol ini adalah persamaan dari piramida ebagai imbol utama yang mewakili miteri peradaban kuno yaitu keluhuran dalam keederhanaan mereka, ilahi dalam propori mereka. Mereka mewujudkan pengetahuan ilahi yang dimiliki oleh yang tercerahkan (illuminated). Dari ini kaum elit ordo Illumintai mendedikaikan diri ebagai okultime, yaitu ahli wari dari kebijakanaan kuno dan menggunakan piramida ebagai imbol kekuaaan di dunia modern.

Puncak segitiga yang tidak sempurna menandakan segitiga batu ata piramid yang terang , mengambang atau hilang, yaitu mewakili kehadiran Ilahi di alam semesta serta dalam setiap manusia. Arti simbolis lain dikaitkan dengan batu penjuru yang hilang sebagai sifat yang belum selesai dari gerakan Tata Dunia Baru ( New Worl Order). Disebutkan bahwa puncak segitiga penjuru dari dari Piramida Besar akan diaktifkan kembali ketika proyek yang telah berusia lama ini menjadi kenyataan. Kaum ordo Illuminati juga menggunakan bangunan piramida untuk merepresentasikan struktur hirarki mereka, dengan cara para elit Ordo illumintai duduk pada puncak piramida untuk menguasai massa yang berkewajiban menopang piramida tersebut ( Jagad, 2013: 31).

\section{e. Pemerintahan}

Pemerintahan Arab saudi menggunakan item kerajaan atau monarki dan Ilam sebagai bentuk pemerintahannya. Alquran dan syariat Islam menjadi dasar dari sistem yang dijalankan. sistem pemerintahan Arab saudi merupakan presidenisil karena dipimpin oleh seorang raja. Raja selain menjadi kepala negara juga memiliki beberapa peran sehingga sitem pemerintahannya disebut sebagai monarki absolut

http://ilmakriboo.worldpress.com/20 13/12/26/sistem-pemerintahansaudi-arabia/diakes 11 Nopember 2015, pukul 08.40). saat ini Arab saudi dipimpin oleh raja Abdullah bin Abdul Azis Al saud, yang diangkat menjadi raja pada tahun 2005 M menggantikan raja Fahd yang telah meninggal. selain sebagai pemimpin negara raja Abdullah bin Abdul Azis Al saud juga merangkap jabatan sebagai perdana menteri dan pemerintahan.

Kerajaan saudi Arabia memiliki landasan bagi sistem pemerintahan di wilayah tersebut, lingkungan resmi yang mengaturnya, unsur-unsur fundamental masyarakat saudi, prinsip-prinsip ekonomi umum yang dilaksanakan kerajaan, jaminan negara terhadap kebebasan dan kehormatan ata kepemilikian khusus, perlindungan atas hak-hak asasi manusia seusai dengan hukumhukum syari'at Islam. Kerajaan itu juga menetapkan hak dan kewajiban negara dan hubungannya dengan negara-negara lain, dan negara memberikan perhatian terhadap Ilmu pengetahuan dan sastra, serta menyediakan perawatan keehatan. Di samping itu, hukum-hukum tentang layanan kemiliteran dan kewajiban warga negara dalam mempertahankan aqidah islamiyah, masyarakat dan tanah air. Undangundang juga menetapkan hal-hal yang berhubungan dengan 
pemerintahan, kehormatan tempat tinggal dan sanksi, hak suaka politik, kewajiban dan hak warga negara asing yang bertempat tinggal di wilayah tersebut. ( http://www.cribd.com/doc/6602356 9/2015 pkl 11.00).

Kerajaan Arab saudi juga menetapkan kekuaaan negara baik yang bersifat judikatif (badan yang menentukan atau menangani masalah/bidang hukum), eksekuti (berkenaan dengan penguruan (pengelolaan, pemerintahan atau penyelenggaraan sesuatu) maupun regulatif(bersangkutan dengan peraturan), dengan mengisyaratkan bahwa pengadilan merupakan kekuasaan yang berdiri sendiri berada di bawah kekuaaan syariat islam sebagaimana menetapkan pembentukan majelis syura serta mencakup urusan keuangan negara dan lembaga pengawasan. Adminitrasi pemerintahan terdiri dari kabinet yang dibentuk pada tahun 1373 H / 1953 M. Majelis ini sekarang mencakup sejumlah departemen yang berkompeten seperti, departemen pertahanan, Luar Negeri, Dalam negeri, keuangan, Ekonomi, perencanaan, perminyakan-pertambangan,

kehakiman, urusan Ilam, wakaf, dakwah dan bimbingan, Pendidikan dan Pengajaran, pendidikan tinggi, kebudayaan dan informasi, perdagangan dan perindustrian, air dan listrik, urusan kota dan pedesaan, haji dan layanan ipil. (http://www.cribd.com/doc/6602356 9/item-daar-Pemerintahan-Kerajaan Arab saudi diakes 11 November 2015 pukul 15.38).

Dari penjelasan tentang kabinet-kebinet yang ada di Arab saudi terebut, secara tidak langsung Arab saudi mengharuskan untuk membuka diplomasi antar negara, termasuk terhadap negara-negara Barat. Hal ini juga sekaligus dimanfaatkan oleh ordo Illuminati untuk ikut andil di dalam diplomasi tersebut meskipun tidak ecara langsung sebab cara yang mereka gunakan adalah cara sistem mind control. Hal ini memperkuat pendapat beberapa ahli tentang hubungan rahasia antara kerajaan Arab saudi dengan kaum Ordo illuminati. seperti diketahui bahwa ordo milluminati adalah kelompok yang memiliki tujuan membuat tatanan dunia baru berdasarkan ajaran Mesir Kuno. Tanda-tanda Ordo illuminati yang paling banyak ditemui adalah mata satu. Di bawah ini adalah salah satu kabinet organisasi kebudayaan dan kesenian bentukan Arab saudi yang menggunakan logo tersebut.

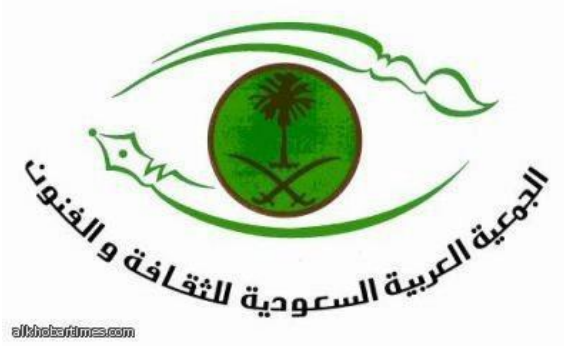

Gambar 4: Lambang organisasi Kebudayaan dan Keenian Arab saudi. (http://generaissalaf.worldpress.com) 
Lambang organisasi kebudayaan dan kesenian ini digambarkan dengan dua kuas dan pena hijau yang melengkung , ditengahnya terdapat lingkaran berwarna hijau dengan gambar pohon kurma dan dua belah pedang. Di bawahnya ada tulian $A l$ Jam'iyyatul ' arabiyyah lit taqafah wal funun dimana tulisannya menyesuaikan lengkungan pena di atasnya. Jika dicermati, bentuk ini secara kasat mata sudah sangat jela menyerupai bentuk sebuah satu mata.

Hasil yang diperoleh dari penelitian semiotik di atas bukan struktur melainkan proses semiotik yang memberikan makna unsur kebudayaan yang dipandang sebagai sebuah tanda. Tujuan utama semiotik adalah memahami kemampuan otak untuk memproduksi dan memahami tanda serta kegiatan membangun pengetahuan tentang seuatu dalam kehidupan manusia ( Danesi dan Perron, 1999" 68-70 dalam Hoed, 2001; 23)

\section{f. Agama}

Mengenai arti agama secara etimologi terdapat perbedaan pendapat, diantaranya ada yang mengatakan bahwa kata agama berasal dari bahasa sansekerta yang terdiri dari dua suku kata yaitu, $a$ berarti tidak dan gama berarti kacau, jadi agama berarti tidak kacau, kata agama dalam bahasa indonesia sama dengan kata diin dalam bahsasa Arab atau religion, dalam bahasa Inggris, la religion dalam bahasa Perancis, dan religie dalam bahasa Belanda, serta die religion dalam bahasa Jerman.
Agama memiliki peran penting dalam sebuah negara sebab dengan agama karakter individu dibentuk. Agama merupakan sesuatu yang suci, yang menjadi pedoman dan tuntunan setiap mayarakat yang berpengaruh besar di dalam negara tersebut. Pengaruh agama khususnya dalam simbolsimbol ajaran di dalamnya maupun monumen-monumen bangunan yang melambangkan kehidupan agama memiliki makna yang sangat besar dalam kehidupan sosial.

Alah atu bangunan menara yang megah di sekitar ka'bah adalah menara Abraj al bait atau fairmont Tower. Menara itu merupakan komplek bangunan tertinggi di dunia. Komplek bangunan yang meliputi bangunan tower penanda waktu sholat, mall, hotel, dan pusatpusat pemuas nafsu manusia tersedia lengkap di tempat itu. setiap wisatawan datang ke kota Mekah untuk menikmati fasilitas-fasilitas yang tersedia di dalamnya. saat ini Mekah bukan lagi menjadi tempat ritual bagi peziarah dan ibadah melainkan juga menjadi objek wisata turi asing. Bangunan ini dirancang oleh para arstek dari Dar Al Handasah Architects dan pelaksanaan pembangunannya dilakukan oleh saudi bin Ladin group. Lokais menasra ini berada di seberang jalan masjid al haram salah satu masjid suci umat Ilam. Jika diperhatikan pada bagian puncak bangunan, maka akan terdapat simbol yang meyerupai bulan sabit yang menghadap ke atas. ( Ezza, 2004:62)

\section{g. Sosial.}


Secara sosial, Arab Saudi merupakan sebuah negara yang menjunjung tinggi nilai kebudayaan.Salah satu ciri khas kebesaran sosial dan budaya bagi bangsa Arab adalah dalam hal berpakaian.Agama dan adat Arab Saudi mengajarkan kebiasaan pakaian yang sesuai untuk pria dan wanita. Apapun pekerjaan atau status sosial, hampir semua busana orang Arab Saudi sama, yaitu pakaian putih yang biasa di sebut "tsawb". Pakaianperempuan Saudi di depan umum, biasanyaakan mengenakan jubah hitam tebal disebut abayah, dengan kerudung menutupi rambutnya.

Sistem sosial masyarakat Arab seperti yang telah dijelaskan di atas sedikit demi sedikit telah mengalami perubahan dari masa ke masa.Perubahan ini berpengaruh juga terhadap perkembangan sistem kehidupan sosial masyarakat, termasuk pada kepolisian.

Seragam kesatuan kepolisian merupakan salah satu pakaian di Arab Saudi yang tidak semua masyarakat memakainya.Seperti seragam kepolisian pada umumnya, pakaian ini berupa baju hem berkerah dengan lengan panjang dan celana panjang, dan juga topi.Seragam kepolisian ini memiliki logo yang berbentuk lingkaran dengan gambar mata satu ditengahnya.Simbol mata satu tersebut, terletak pada lengan tangan kiri pada seragam, dan juga pada lencana di topi.Penulis menyayangkan, mengapa pemerintah menggunakan logo mata satu dalam seragam kepolisian di negara dengan hukum Syariat Islam ini.Sebab logo mata satu merupakan simbol utama di dalamOrdo Illuminati. (Samantho, 2014: 173)

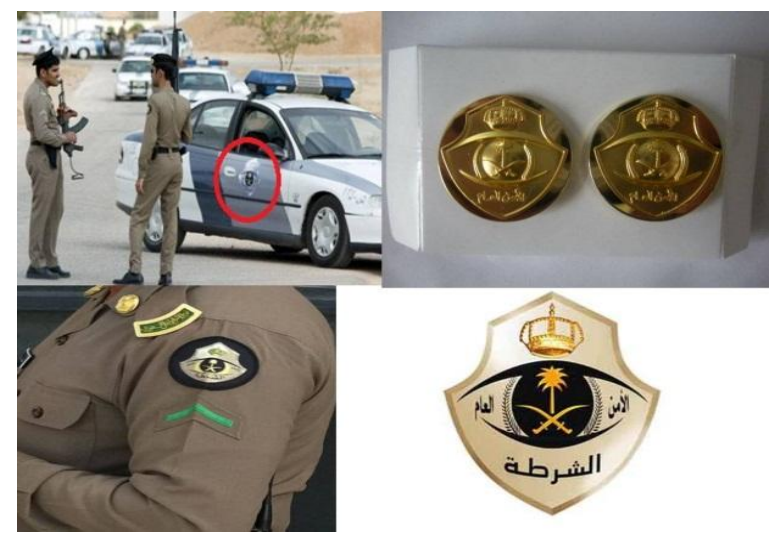

Gambar 5: Logo Kepolisian Arab Saudi (https://kupretist.wordpress.com)

Seperti yang telah di bahas pada pembahasan simbol Ordo Illuminati sebelumnya, logo ini bersifat melihat ke segala penjuru arah.Menurut penulis, maksud dari dibuatnya $\log o$ tersebut pada seragam kepolisian Arab Saudi, bertujuan menjadikan kepolisian yang mampu melihat ke segala sisi ketika terjadi sebuah peristiwa.Ini tidak jauh berbeda dengan tujuan Ordo Illuminati di atas, yakni 
memperhatikan segala gerak-gerik masyarakat di seluruh dunia.

\section{Kesimpulan}

Dari penjelasan yang telah dijabarkan oleh penulis di atas, maka kesimpulan dari penelitian ini adalah:

1. Latarbelakang pemakaian simbol Ordo Illuminati oleh muslim di Arab Saudi berawal dari adanya diplomasi antara Arab Saudi dan negara barat, kemudian membuka peluang Ordo Illuminati untuk menyusupkan simbol-simbolnya sebagai bagian dari missi yang ingin dicapai.

2. Sebagai organisasi ideologi tersembunyi dan bekerja di balik layar, organsasi Ordo Illuminati memiliki tujuan untuk membentuk tatanan dunia baru ( New world Order) yang telah memasuki di berbagai banyak sistem wilayah negara-negara di dunia, baik negara-negara yang sudah maju maupun berkembang hingga akhirnya berperan aktif dalam berbagai bidang. salah atu negara yang berhasil disusupi adalah saudi Arabia. Wilayah kerajaan yang nota bene bersasakan undangundang Alquran dan syari'at Islam, ternyata negara ini adalah wilayah yang dibuat oleh seorang keturunan yahudi bernama Mordakhai bin Ibrahim hingga akhirnya lahirlah keturunanketurunan para raja Arab saudi, yang pada akhirnya banyak membuat relasi terhadap negaranegara barat sebagai negara yang mengendalikan ordo Ilmmuninati.

3. Hubungan diplomatik antara pemerintah Arab Saudi dan negara-negara barat tersebut menghasilkan sebuah pemikiran yang lebih modern.Pemikiran tersebut menghasilkan banyak perubahan dari berbagai aspek kehidupan masyarakat Muslim di Arab Saudi. Aspek-aspek tersebut mencakup aspek sosial, seni bangunan, dan seni musik. Salah satu caraOrdo Illuminati bekerja dan berkarya yaitu dengan menyusupkan simbol-simbol mereka.

\section{Daftar Pustaka}

Al-Qur'an dan Terjemahannya. Departemen Agama RI. 2002. . 2008. Kamus Besar Bahasa Indonesia. Jakarta: Pusat Bahasa Departemen Pendidikan Indonesia.

Berger, Arthur Asa. 2010. Pengantar Semiotika: Tanda-Tanda Dalam Kebudayaan Kontemporer. Yogyakarta: Penerbit Tiara Wacana.

Budiman, Kris. 2011. Semiotika Visual: Konsep, Isu, dan Problema Ikonitas. Yogyakarta: Jalasutra.

Ezza, Muhammad Abu. 2014. SimbolSimbol Ordo Illuminati di Arab Saudi. Yogyakarta:Pyramid.

Gray, Jerry Duane. 2005. Bayang Gurita Mengungkap Pergerakan Freemason dan Organisasi Anti Islam Dunia. Jakarta: Iqra’ Insan Press.

Junus, Rifky. 2013. Membongkar Ordo Illuminati.Seven

Books.Yogyakarta. 
Kriyantono, Rachmant. 2006. Teknik Praktis Riset Komunikasi. Jakarta: Kencana.

Makow, Henry. 2011. Ordo Illuminati: Dunia Dalam Genggaman Perkumpulan Setan. Jakarta Selatan: Ufuk Press.

Purbawati, Jagad A. 2013. The New World Order Konspirasi Global Para Penyembah Iblis Menaklukan Dunia. Jakarta Timur: Pustaka Al-Kautsar.

Simmons, Matthew R. 2005. Twilight In The Desert: The Coming Oil Saudi Shock and The World Economy. New Jersey: John Wiley \& Sons, Inc.

Storey, John (2010).Cultural Studies dan Kajian Budaya Pop: Pengantar Komprehensif Teori dan Metode. Terjemahan.
Yogyakarta: Jalasutra.

Tauhidi, M. Pizaro Novelan. 2014. Zionis \& Syiah Bersatu Hantam Islam. Solo: PT Aqwam Media Profetika.

(https://dwiheriyanto.wordpress.com/2 008/09/20/foto-

fotomekkahmasamendatang /diakses pada 13 Desember 2015, 11.34 WIB)

(http://www.arrahmah.com/news/2013/ 05/27/arab-idol-zionisme-yahudidinegeri-negeri-muslim-timurtengah.html diakses pada 20 Oktober 2015 pukul 22.00).

(http://www.digitalproductionm e.com/article-8461-mbc-studioslighting-supplied-by-prolites/ diakses pada 20 Desember 22.20 WIB) 